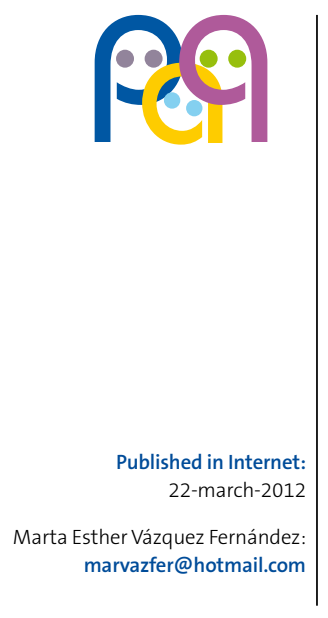

\section{毫}

Objective: to determine the coverage rate for unfunded childhood vaccines, and whether they were administered correctly, in children seen recently at an urban healthcare center in a middle socioeconomic area.

Material and methods: we performed a cross-sectional descriptive study, analyzing the pneumococcus, rotavirus, and varicella vaccination records in the computerized clinical histories of every child, seen by either of two pediatricians, who could have been given all the doses recommended for these vaccines.

Results: the study included 162 children of immunization age for pneumococcal disease, 112 for rotavirus, and 160 for varicella. The coverage rates for complete immunization as specified in the recommendations of the Advisory Committee on Vaccines were $64.81 \%, 66 \%$, and $58.1 \%$, respectively. $11.73 \%$ of those who started pneumococcal vaccination and $2.68 \%$ of those who started rotavirus vaccination did not complete the recommended number of doses. There were no significant differences in vaccination rates between the two pediatricians.

Key words:

- Vaccination

- Pneumococcus • Rotavirus $\bullet$ Varicella - Vaccination coverage rates
Conclusions: we found evidence of mid-range vaccine coverage rates and incomplete vaccination courses. The financial resources of the families and the educational efforts of the Nursing and Pediatrics staff account for these vaccination rates. We do not know the epidemiological effect of these vaccination rates on the diseases that they are meant to prevent. We need to promote equity in healthcare services when it comes to immunizations.

\title{
Vacunas infantiles no financiadas, ¿cuál es la cobertura en un centro de salud urbano?
}

Palabras clave:

- Vacunación

- Neumococo

- Rotavirus - Varicela

- Cobertura vacunal
Objetivo: determinar la tasa de cobertura de las vacunas infantiles no financiadas y si son administradas correctamente, en los niños atendidos recientemente en un centro de salud urbano de nivel socioeconómico medio.

Material y métodos: se realiza un estudio transversal, descriptivo, analizando el registro de vacunas frente al neumococo, rotavirus y varicela de la historia informatizada de los niños atendidos por dos pediatras, que hayan podido recibir todas las dosis recomendadas.

Resultados: se han incluido 162 niños susceptibles de vacunación frente a neumococo, 112 para el rotavirus y 160 para varicela. Las tasas de cobertura para la vacunación completa según recomendaciones del Comité Asesor de Vacunas han sido el 64,81, el 66 y el 58,1\%, respectivamente. El 11,73\% de los que inician la vacunación frente al neumococo y el $2,68 \%$ del rotavirus no completan el número de dosis recomendadas. No hubo diferencias de vacunación significativas entre ambos pediatras.

Conclusiones: nos encontramos con unos niveles de cobertura vacunal medios y con pautas incompletas. Los recursos económicos de las familias y la labor educativa del personal de Enfermería y Pediatría son los responsables de estas tasas vacunales. Desconocemos el efecto epidemiológico sobre las enfermedades que se quieren prevenir, de estas tasas vacunales. Es necesario fomentar la equidad en las prestaciones sanitarias relacionadas con las vacunas. 


\section{INTRODUCTION}

At present, there are several childhood vaccines that are not included in the official immunization schedule of most autonomous communities ${ }^{1}$. It is up to parents to choose whether their children are immunized against additional infectious diseases, and to pay for these immunizations ${ }^{2}$.

Under these circumstances, primary care pediatricians, as agents of public healthcare in the community and personal advocates of the child, and following the recommendations of the Advisory Committee on Vaccines of the Spanish Association of Pediatrics, believe that all parents should have the right to be informed and make decisions about the preventative measures that can benefit their child. Thus, in anticipation of immunizations, oral and written information about vaccines unfunded by the healthcare system is routinely given during health check-ups.

In spite of this, vaccination coverage rates for this set of vaccines are not usually estimated directly from the records in our clinical practices. The main objective of this work is to determine the vaccination rates for the children seen most recently at our healthcare center and whether they received the recommended number of doses at the proper intervals for the three vaccines unfunded by the National Healthcare System in our autonomous community (Castile and Leon): the pneumococcal conjugate vaccine, the rotavirus vaccine, and the varicella vaccine.

\section{MATERIALS AND METHODS}

We did a retrospective, cross-sectional, descriptive study based on the vaccination data included in the computerized electronic medical histories stored in the MEDORA program. The end date for the inclusion of data was December 30, 2011. The target population was selected by gathering the most recent immunization records for the children who could have received all the doses required for a complete vaccination course in an urban healthca- re center located in a middle socioeconomic area, the Centro de Salud Arturo Eyries, which has two pediatricians and one nurse and serves an average of 2350 children between the two physicians' patient lists. Children with limited records or no records were excluded from the study, as were those who had been removed from the patient list due to transfer to another healthcare center or relocation to another city, and those who started being seen at the center when the study was already underway.

When it came to immunization against pneumococcal disease, we took into account the number of administered doses and the age at the start of the course. Thus, the following groups were established for analysis: children under six months of age that received four doses, children between six months and a year of age who received three doses, and children older than one year that were given two doses. For all subsets, the last dose needed to have been administered before the age of two. Thus, children over two years of age who had been born between January 1, 2009 and January 1, 2010 were included in the study, the total of which was 162 children.

The subject group for the rotavirus vaccine included those children older than six months of age born between September 1, 2009 and June 1, 2010 , for a total of 112 children. Only nine months' data were analyzed because vaccination against rotavirus was suspended from June to December 2010 , due to quality concerns pertaining to the potential contamination of the vaccines with fragments of porcine circovirus. A child was considered correctly immunized if he had been given three doses before 26 weeks of age, as is specified in the summary of product characteristics of RotaTeq ${ }^{\circledR}$, the vaccine available in pharmacies (at the time of the study).

Considering that the recommended age range for immunization against varicella is between 12 and 15 months, the data for this vaccine corresponds to the cohort of children older than 16 months (an additional calendar month is allowed as the upper time limit for a child to be considered correctly im- 
munized), born between September 12009 and September 1 2010, for a total of 160 children. We could not assess the coverage for the second dose, at three or four years of age, because it was not possible for the children in our study to have completed the two-dose vaccination course recommended since $2008^{1}$.

Last of all, we assessed whether vaccination status was influenced by the reporting pediatrician using Pearson's chi-squared test and the software Epidat $^{\circledR} 3.1$.

\section{RESULTS}

We must note that we observed that three types of conjugate vaccines were used during the period of analysis of immunization against pneumococcal disease: heptavalent (Prevenar ${ }^{\circledR}$ ), decavalent (Synflorix ${ }^{\circledR}$ ) and 13 -valent (Prevenar13 ${ }^{\circledR}$ ). Regardless of the vaccine administered, out of the total subject population (162 children) 80.25\% ( $n=130$ ) started a vaccination course with one or more doses, and $19.76 \%(n=32)$ did not receive any doses. Of all the children that started the vaccination course, $11.73 \%$ ( $n=19)$ were immunized incorrectly because they were missing doses, $2.47 \%$ (n $=4$ ) had been given three doses, with the first dose administered between 6 and 12 months of age, and $1.23 \%(n=2)$, had received two doses between the first and the second year of life. Only $64.81 \%$ of the total subject population received four doses: the first one at two months of age, the second one at months four or five, the third one at six or seven months, and the fourth one between 12 and 24 months, usually at 18 months of age. The results of the analysis are shown in Table 1.

When it comes to immunization against rotavirus, the results, shown in Table 2, are the following: $66 \%$ of children of immunization age received the correct course of three vaccine doses before six months of age, $31.25 \%$ were given no doses, thus remaining unvaccinated, and $2.68 \%$ missed at least one dose, and therefore were incorrectly vaccinated.

Last of all, $58.1 \%$ of the children were vaccinated against varicella, while $41.9 \%$ of the children remained unvaccinated (Table 3).

We did not find significant differences in the vaccination rates depending on which pediatrician cared for the child and provided information to the parents: $P=0.557$ for the pneumococcal vaccine, $P$ $=0.753$ for the rotavirus vaccine, and $P=0.732$ for the varicella vaccine. There were also no differences among the children with incomplete vaccination courses against pneumococcal disease $(P=$ $0.409)$ and rotavirus $(P=0.582)$.

\section{DISCUSSION}

Although our study is of a local nature, its figures offer a realistic approximation to the actual coverage rates for the three childhood immunizations that are not included in the official schedule. The results obtained show similar vaccination rates for immunization against pneumococcal disease and

Table 1. Immunization against pneumococcal disease. Period of January 1, 2009, through January 1, 2010

\begin{tabular}{|l|c|c|c|c|c|}
\hline & $\begin{array}{c}\text { Correctly } \\
\text { vaccinated } \\
\text { (4 doses) }\end{array}$ & $\begin{array}{c}\text { Vaccinated } \\
\text { (3 doses) } \\
\mathbf{6 - 1 2} \text { months }\end{array}$ & $\begin{array}{c}\text { Vaccinated } \\
\text { (2 doses) } \\
\mathbf{1 2 - 2 4} \text { months }\end{array}$ & $\begin{array}{c}\text { Incorrectly } \\
\text { vaccinated } \\
\text { (missing doses) }\end{array}$ & Unvaccinated \\
\hline Pediatrician 1 & $\begin{array}{c}64,66 \% \\
(\mathrm{~N}=64)\end{array}$ & $\begin{array}{c}4,04 \% \\
(\mathrm{~N}=4)\end{array}$ & $\begin{array}{c}1 \% \\
(\mathrm{~N}=1)\end{array}$ & $\begin{array}{c}12,12 \% \\
(\mathrm{~N}=12)\end{array}$ & $\begin{array}{c}18,18 \% \\
(\mathrm{~N}=18)\end{array}$ \\
\hline Pediatrician 2 & $65,08 \%$ & $0 \%$ & $1,59 \%$ & $11,11 \%$ & $22,22 \%$ \\
& $(\mathrm{~N}=41)$ & $(\mathrm{N}=0)$ & $(\mathrm{N}=1)$ & $(\mathrm{N}=7)$ & $(\mathrm{N}=14)$ \\
\hline Total & $64,81 \%$ & $2,47 \%$ & $1,23 \%$ & $11,73 \%$ & $19,76 \%$ \\
& $(\mathrm{~N}=105)$ & $(\mathrm{N}=4)$ & $(\mathrm{N}=2)$ & $(\mathrm{N}=19)$ & $(\mathrm{N}=32)$ \\
\hline
\end{tabular}


Table 2. Immunization against rotavirus. Period of September 1, 2009, through June 1, 2010

\begin{tabular}{|l|c|c|c|}
\hline & Complete Vaccination & Incomplete vaccination & Unvaccinated \\
\hline Pediatrician 1 & $63,27 \%$ & $2,04 \%$ & $34,69 \%$ \\
& $(\mathrm{~N}=31)$ & $(\mathrm{N}=1)$ & $(\mathrm{N}=17)$ \\
\hline Pediatrician 2 & $68,25 \%$ & $3,18 \%$ & $28,57 \%$ \\
& $(\mathrm{~N}=43)$ & $(\mathrm{N}=2)$ & $(\mathrm{N}=18)$ \\
\hline Total & $66,07 \%$ & $2,68 \%$ & $31,25 \%$ \\
& $(\mathrm{~N}=74)$ & $(\mathrm{N}=3)$ & $(\mathrm{N}=35)$ \\
\hline
\end{tabular}

rotavirus, and a lower rate for immunization against varicella, perhaps due to the perception that the latter disease involves a more banal process and because our autonomous community offers this immunization at 11 years of age if the child has not had the disease before.

We believe that these figures are too low, considering that the vaccination coverage rates for vaccines included in the official immunization schedule, according to the Ministry of Health, are greater than $95 \%$ both for primary vaccination and for booster doses 3 , and that vaccination rates greater than $70-80 \%$ are needed to achieve an adequate herd immunity 4 .

Nevertheless, these rates could be considered high, given that these vaccines can be labeled as "unfunded" and "not included in the immunization schedule" and in comparison to the vaccine coverage data obtained by authors of other local studies $^{5-7}$; we should also bear in mind that the pneumococcal vaccine coverage in children in Spain in 2003, estimated by means of the number

Table 3. Immunization against varicella. Period of September 1, 2009, through September 1, 2010

\begin{tabular}{|l|c|c|}
\hline & Vaccinated & Unvaccinated \\
\hline Pediatrician 1 & $\begin{array}{c}59,2 \% \\
(\mathrm{~N}=58)\end{array}$ & $\begin{array}{c}40,8 \% \\
(\mathrm{~N}=40)\end{array}$ \\
\hline Pediatrician 2 & $\begin{array}{c}56,45 \% \\
(\mathrm{~N}=35)\end{array}$ & $\begin{array}{c}43,55 \% \\
(\mathrm{~N}=27)\end{array}$ \\
\hline Total & $58,1 \%$ & $41,9 \%$ \\
& $(\mathrm{~N}=93)$ & $(\mathrm{N}=67)$ \\
\hline
\end{tabular}

of doses sold in Spanish pharmacies, stood at about $50 \%$, with variations between the different autonomous communities ${ }^{8}$. We believe that the rates we found are due to the health education efforts of the Nursing and Pediatrics staff, who at the time of each check-up remind parents of the date of the next vaccination. As expected, we did not find significant differences between the vaccination coverage rates of children seen by each of the pediatricians, since both physicians serve populations of similar socioeconomic level and offer the same recommendations in oral and written form during health check-ups.

It seems that the main impediment for administration of these vaccines is their elevated price. The pneumococcal vaccine (four doses) costs around 300 euro, the rotavirus vaccine (three doses) 200 euro, and the varicella vaccine (two doses) around 120 euro. Another factor is parents' perception that infants are given a high number of shots.

We want to underscore as a significant finding the sizable percentage of children that do not receive the full course of four doses recommended against pneumococcal disease (15.43\%) and the lesser percentage of children with incomplete immunization against rotavirus (2.68\%). At present, there are no data on the safety and efficacy of either vaccine when incomplete vaccination courses are given, nor are there data for the "alternative" vaccination courses for older children with fewer doses, as it pertains to both disease prevention and herd immunity ${ }^{10}$. The cause for this could not be determined with any certainty: neglect, economic constraints, or faulty reasoning in regards to vaccine efficacies. 
We do not know the epidemiological effects of these mid-range vaccination coverage rates and the rates of incomplete immunization on the diseases that are meant to be prevented ${ }^{9}$. The main concerns are the shift of cases toward older age groups, as well as the emergence of nonvaccine serotypes leading to more complications or more severe forms of the disease, associated to an uneven herd immunity effect and the decreased circulation of the infectious agents contained in the vaccines $^{10-13}$.

At present, there is variability in the inclusion of these vaccines between the autonomous communities of Spain 14 and in other European 15 and American16 countries:

- The pneumococcal vaccine is included only in the immunization schedule of Madrid, since 2006. It is also included in North American countries and neighboring Europe countries.

- The rotavirus vaccine is not included in the immunization schedule of any of the autonomous communities in Spain. It is administered routinely in America, and in only a few European countries, such as Austria.

- In Castile and Leon, the varicella vaccine has been included since 2005 in the immunization schedule for 11-year-old children who have not experienced the disease. However, the Spanish Association of Pediatrics recommends the immunization of all children between 12 and 15

\section{BIBLIOGRAPHY}

1. Moreno-Pérez D, Álvarez García FJ, Arístegui Fernández J, Barrio Corrales F, Cilleruelo Ortega MJ, Corretger Rauet JM, et al. Calendario de vacunaciones de la Asociación Española de Pediatría: recomendaciones 2012. An Pediatr (Barc). 2012;76(1):42.e1-e23.

2. Merino Moína M. Vacunas infantiles ¿cuál es nuestro papel como pediatras de Atención Primaria? [en línea] [consultado el 23/01/2012] Disponible en www.spapex.es/vacunas.htm

3. Cobertura de vacunas. Datos estadísticos, total nacional 2002-2010. Ministerio de Sanidad, Políticas Socia- months of age, and a second dose at three and four years of age ${ }^{17}$. Madrid and Navarre are the only autonomous communities where the varicella vaccine is included in the official schedule for the second year of life. In the United States and various states in Canada it has been funded for several years. Some countries in Europe are establishing routine immunization against varicella, such as Germany, Greece and Italy.

\section{Conclusions}

We achieved vaccination coverage rates that are inadequate for attaining full herd immunity, and a considerable percentage of children were vaccinated incorrectly.

We think that the elevated price could be the main discouraging factor that led to non-vaccination.

The variability in the administration of these vaccines must be taken into account when their epidemiological effect on the corresponding diseases is assessed. It would be necessary to establish a nationwide system to survey the coverage rates for these unfunded vaccines.

We propose performing more studies of direct and indirect costs to elucidate the need of their inclusion in the official childhood immunization schedules, to ensure equity between individuals of different economic backgrounds.

les e Igualdad [en línea] [consultado el 23/01/2012] Disponible en www.msc.es/profesionales/saludPubli ca/prevPromocion/vacunaciones/coberturas.htm

4. Ministerio de Sanidad, Políticas Sociales e Igualdad. Varicela. Recomendaciones de vacunación y sus implicaciones en salud pública, 2005 [en línea] [consultado el 23/01/2012]. Disponible en www.msc.es

5. Ramos Salas E, Díez Delgado FJ, Salazar Agulló M, Ramos Pleguezuelos FM. Coberturas de vacunación neumocócica en menores de 2 años en 2 zonas de Almería capital. Vacunas. 2008;9(1):12-8.

6. Vila A, de Diego C, Salchench E, Saun N. Coberturas de vacunación antineumocócica con vacuna hepta- 
valente conjugada en la población infantil de Tarragona-Valls. Aten Primaria. 2007;39:507.

7. Hernández Pascual M, Ruiz Serrano A, Rodríguez Ortiz de Salazar MI, Casado López M, López de Andrés A. Cobertura vacunal frente al rotavirus en la población infantil del Área 8 de la Comunidad de Madrid. Vacunas. 2008;9(3):117-20.

8. Comité Asesor de Vacunas de la AEP. Comentarios del Comité Asesor de Vacunas (CAV) de la Asociación Española de Pediatría (AEP) al documento emitido por el Ministerio de Sanidad (DM) español en abril de 2006 "Enfermedad Invasora por Streptococcus pneumoniae. Implicaciones de la vacunación con vacuna conjugada heptavalente" [en línea] [consultado el 23/01/2012]. Disponible en http://vacunasaep.org/ documentos/comentarios-del-cav-al-documentosobre-neumococo-del-ministerio-de-sanidad (actualizado el 05-04-2006).

9. American Academy of Pediatrics. Active and passive immunization. En: Pickering LK, Baker CJ, Kimberlin DW, Long SS (eds.). 2009 Red Book: report of the Committee on Infectious Diseases. 28th ed. Elk Grove Village, IL: American Academy of Pediatrics; 2009.

10. Singleton RJ, Hennessy TW, Bulkow LR. Invasive pneumococcal disease caused by non vaccine serotypes among Alaska native children with high levels of 7-valent pneumococcal conjugate vaccine coverage. JAMA. 2007;297:1784-92.

11. Black S, Shinefield H, Baxter R. Impact of the use of heptavalent pneumococcal conjugate vaccine on di- sease epidemiology in children and adults. Vaccine. 2006;24 (suppl 2):S2-S80.

12. Ruiz-Palacios GM, Pérez-Schael I, Velázquez FR. Safety and efficacy of an attenuated vaccine against severe rotavirus gastroenteritis. N Engl J Med. 2006;354:11-22.

13. Bayer $\mathrm{O}$, Heininger $U$, Heiligensetzer $C$, Von Kries R. Metaanalisis of vaccine effectiveness in varicella outbreaks. Vaccine. 2007;25:6655-60.

14. Bernaola Iturbe $E$, Giménez Sánchez F, Baca Cots $M$, de Juan Martín F, Diez Domingo J, Garcés Sánchez M. Recomendaciones de vacunación de la Asociación Española de Pediatría 2008. Vacunas. 2008;9(2):80-5.

15. Asociación Española de Pediatría de Atención Primaria. Calendarios de vacunación españoles y extranjeros [en línea] [consultado el 23/01/2012]. Disponible en www.aepap.org/vacunas/calendarios-espanoles/ calendarios-extranjeros

16. Advisory Committee on Immunization Practices (ACIP). CDC. Recommended immunization schedules for persons aged 0-18 years. Unites States 201. MMWR. 2011;60(05);1-4.

17. Ministerio de Sanidad y Consumo. Dirección General de Salud Pública. Varicela: epidemiología y situación actual. Vacunas: características y eficacia/efectividad. Recomendaciones de vacunación y sus implicaciones en Salud Pública. 2005 [en línea] [consultado el 23/01/2012]. Disponible en www.msc.es/ciuda danos/proteccionSalud/vacunaciones/docs/VARICE LA1.pdf 